\title{
Effect of nutrition on oxidative stress
}

\author{
E. Sawosz ${ }^{1,3}$, A. Chwalibog ${ }^{2}$, T. Niemiec ${ }^{1}$, I. Kosieradzka ${ }^{1}$ \\ and J. Skomial ${ }^{1}$
}

\author{
Warsaw Agricultural University, \\ ${ }^{1}$ Department of Animal Nutrition and Feed Science \\ Ciszewskiego 8, 02-786 Warsaw, Poland \\ The Royal Veterinary and Agricultural University, \\ ${ }^{2}$ Department of Animal and Veterinary Basic Sciences \\ Bülowsvej 13, Frederiksberg C, Denmark
}

\begin{abstract}
Although oxygen is a necessary molecule for catabolic and anabolic processes in animals and humans, it is also a main source of reactive oxygen species (ROS). Oxidative stress occurs when the amount of generated ROS exceed cellular antioxidant defences, causing oxidative damage of DNA structure and consequently failure of essential pathways of lipids, proteins and carbohydrates metabolism. Mitochondrial respiratory chain is the main site of free radicals with genotoxic properties. ROS is genotoxic not only in relation to sensitive mitochondrial DNA but also to nuclear DNA and much attention has been paid to its oxidative damage. It is supposed that the increase of a lifespan can be achieved by energy restriction causing decreased metabolic rate and therefore reducing intensity of oxidation and generation of ROS. The paper describes our recent results concerning oxidative effects of restricted energy supply and administration of ubiquinone, vitamins $\mathrm{C}$ and $\mathrm{E}$, and taurine on different cellular and morphological parameters of oxidative stress in rats, pigs and horses. Based on the novel literature and own experiments it is concluded that ROS generation is a necessary element of life and the action of antioxidative network, being related to all essential life processes, is orchestrated by requirements for ROS.
\end{abstract}

KEY WORDS: oxidative stress, DNA oxidation, reactive oxygen species, rat, pig

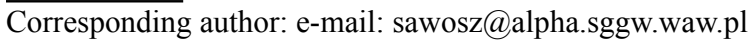




\section{REACTIVE OXYGEN SPECIES}

On our planet exist two categories of life form; photosynthesizing plants that capture solar energy (photons) and use it to produce reduced carbonaceous compounds; and animals and human who eat reduced compounds, part of them change to own tissues, part of them oxidize with release energy and part of them excrete (McCord, 2000). Aerobic oxidation of nutrients is the most efficient source of energy for the body, but at the same time stimulates synthesis of toxic reactive oxygen species (ROS) and in consequence can cause an oxidative stress. Body metabolism is the main contributor of ROS, which paradoxically are generated by the most important metabolic processes sustaining life, growth and development.

A free radical is described as a atomic or molecular species capable of independent existence that contains one or more unpaired electrons in one of the molecular orbitals (Halliwell and Gutteridge, 1989). Original source of free radicals is oxygen. Molecular oxygen (dioxygen ${ }^{3} \mathrm{O}_{2}$ ) has two unpaired electrons with parallel spin in different antibonding orbitals, so ${ }^{3} \mathrm{O}_{2}$ is a free radical biradical. Oxygen is a relatively stable ROS caused by this kind of spin restriction, however, it is capable of accepting electrons, especially via enzymatic reaction and therefore becomes a very strong oxidizing agent. Oxygen may be a source of following main ROS:

- Superoxide anion $\left(\mathrm{O}_{2}^{-}\right)$is formed from one electron reduction of oxygen and can easily dismuate to $\mathrm{H}_{2} \mathrm{O}_{2}$. Although, the superoxide radical is not highly reactive with DNA, it is rapidly reacting with compounds containing SH-groups (cystein), as well as with ascorbate, NADH, collagen and has a high affinity to iron, dissolving it from proteins. $\mathrm{O}_{2}-$ diffuses poorly across cell membranes (Slater et al.,1995; Bartosz, 2003)

- Hydrogen peroxide $\left(\mathrm{H}_{2} \mathrm{O}_{2}\right)$ is formed from dysmutation of $\mathrm{O}_{2}-$ It is less reactive than the superoxide radical, but actively oxidizes $\mathrm{SH}$ groups and ions of transitional metals. It can easily diffuse across cell membranes but it also destroys them, especially in the present of histidin (Bartosz, 2003)

- Hydroxyl radical $(\mathrm{OH})$ is formed from $\mathrm{H}_{2} \mathrm{O}_{2}$ in Fenton reaction catalysed by transition metals. Hydroxyl radicals attack all protein, lipids and DNA indiscriminately, initiating destructive free-radical chain reactions that spread damage and destruction. (McCord, 2000).

Oxygen is also a source of other stress-related molecules. ROS is generated in different cell and tissue structures as a consequence of a variety of enzymatic and non-enzymatic processes. Oxidative stress occurs when ROS and oxidativestress related molecules generated in the extracellular environmental or within the cell exceed cellular antioxidant defences and causes cytotoxic consequences for lipids, proteins, carbohydrates, and most critical for DNA (Cadenas, 1989). 
The main places of ROS production are mitochondrial respiratory chain, electron transport chain (in microsomal, mitochondrial and nucleic membranes), peroxisomes, desaturases in endoplasmic reticulum and also in phagocytizing cells. Oxidative stress contributes to all inflamatory diseases: arthritis, vasculitis, glomerulonephritis, lupus erythematosus, adult respiratory distress syndrome, ischaemic diseases, stroke, intestinal ischaemia, hemochromatosis, acquired immunodeficiency syndrome, emphysaemia, organ transplantation, gastric ulcers, hypertension and preeclampsia, neurologic diseases, Alzheimer's disease, Parkinson disease, amyotrophic lateral sclerosis, muscular dystrophy, alcoholism, smoking-related diseases and many others (McCord, 2000).

\section{OXIDATIVE STRESS INFLUENCES DNA HOMEOSTASIS}

When DNA is attacked by oxygen free radicals, one of the DNA bases called guanine is transformed to 8-hydroxy-2-deoxyguanosine. Product of hydroxylation at C8 position of 2'-deoxyguanosine is measured at a trace level (picogram amounts) as an indicator of DNA damage (Soultanakis et al., 2003). 8-oxo-2'-deoxyguanosine (8-oxodG) is a product of oxidative modyfication and can be incorporated into DNA, causing A:T to C:G mutations (Kasprzak and Białkowski, 2000). Moreover, the DNA single-strand breaks production is related to concentration of 8-hydroxy-2 -deoxyguanosine (8OHdG) in DNA (Toyokuni and Sagripanti, 1996). The formations of 8-OHdG in DNA is likely to be involved in mutagenesis and cancerogenesis (Asami et al., 1996). The natural genetic code is altered by changes in the individual nucleotide bases $(A, C, G, T)$ in double-helix DNA molecules and point mutations are generated by these changes. The point mutations are inbuilt into future cell generation as the cells replicate and in consequence lead to mutagenesis and cancerogenesis. Our cell nucleus has about $50 \mathrm{~cm}$ of DNA requiring a 50,000-fold reduction in length to fit into the nucleus and nuclear matrix (Higuchi, 2003). Thus, DNA is a complex and a powerful structure requiring an efficient and strong protection, but still it has to be considered that degraded DNA is a source of residues of yet unknown activities.

Mitochondrial respiratory chain accounts for most of the superoxide generated in the cell with leakage sites at complex I (dehydrogenase NADH) and at ubisemiquinone (Riley, 1994). Generated superoxide radical can be a source of subsequent ROS, including hydroxyl radical with genotoxic properties. When positioned close to mitochondrial DNA it exhibits higher amounts of steady state oxidative damage compared with nuclear DNA (Yakes and Van Houten, 1997). 8-oxo-2'-deoxyguanosine has been shown to be present in mitochondrial DNA (mtDNA) at a level 16 fold higher than in nuclear DNA, what is consistent with 
the high levels of ROS generated in the oxidative enzymes chain. According to Barciszewski et al. (1995) an age-associated accumulation of 8-OHdG in human mtDNA in the muscle takes place. In a subject below the age of 55 years the level of $8-\mathrm{OHdG}$ in mtDNA was under $0.02 \%$ of total $8-\mathrm{OHdG}$, while it reached a level of $0.51 \%$ at the age of 85 years. In accordance with the "oxidative-damage idea of aging" the ageing is caused by an increase in the steady-state levels of reactive oxygen species and by proton "leaks".

Such events can also result from mutations in respiratory chain enzymes (Martin and Loeb, 2004). Trifunovic et al. (2004) demonstrated that knockout mice [defective in mtDNA polymerase- $\gamma$-enzyme responsible for mtDNA repair processes (Martin and Loeb, 2004)] developed an mtDNA mutator phenotype with a three fold to five fold increase in the level of point mutations, as well as increased amounts of deleted mtDNA. This increase in somatic mtDNA mutations is associated with reduced lifespan and premature onset of ageingrelated phenotypes such as weight loss, reduced subcutaneous fat, alopecia, kyphosis, osteoporosis, anaemia, reduced fertility and heart enlargement. Lack of mitochondrial superoxide dismutase (MnSOD) in knockout mouse caused death within a few days after birth ( $\mathrm{Li}$ et al., 1995). These experiments indicate that overproduction of superoxide radical in mitochondria is highly dangerous for the body.

It is supposed that the increase of a lifespan of humans and animals can be achieved by energy restriction causing decreased metabolic rate (Fu at el., 2004). Therefore by "reducing intensity of oxidation" in the mitochondrial respiratory chain it is possible to sustain metabolic efficiency for a prolonged period of life.

Effects of dietary restriction on oxidative/antioxidative state in pigs have been investigated by Sawosz et al. (2004). A restricted supply of protein and energy had no effect on the activity of antioxidative enzymes $\mathrm{ZnCuSOD}$, GPx, as well as on the total antioxidative status in serum. Further, there was no effect on the concentration of the end products of lipid peroxidation (TBA-RS) in serum, and on the level of oxidative degradation of DNA (8-oxodG) in the liver. We also observed the influence of addition of ubiquinone to a diet for pigs on the redox state by strengthening ubiquinone complex against electron leak in the respiratory chain. However, the addition of ubiquinone had no effect on homeostasis of redox state in blood (SOD, GPx, TBA-RS, TAS) and in the liver (8-oxodG).

ROS is genotoxic not only in relation to sensitive mtDNA but also to nuclear DNA (ncDNA) and RNA. ncDNA is the key molecule carrying the genetic information, and much attention has been paid to its oxidative damage. More than 20 different modifications are supposed to be formed in DNA by the action of $\mathrm{OH}$. This radical is responsible for DNA damage, such as scission of DNA strands (Higuchi, 2003), strand breaks or modification of pyrimidine, as well as 
purine bases (Barciszewski et al., 1995) and formation of DNA-protein cross links (Dizdaroglu, 1991).

DNA breaks are classified into single and double-strand DNA breaks. However, biological role of this phenomenon is not clarified; generally singlestrand cleavage of DNA plays a role as a signal to induce apoptosis, being controlled by the repair enzyme system. Double strand DNA breaks can lead directly to chromosomal aberration and mutagenesis (Lobrich et al., 1994) but also to apoptosis or necrosis - two different incidents of cell death. A very important factor responsible for the process of cells' death seems to be a size of molecules produced during DNA oxidative degradation and their availability for enzymes involved in apoptosis. The content of 8-oxodG in DNA may be a reason for creation of giant DNA fragments or high molecular weight DNA fragments (Higuchi, 2003) unavailable for cells enzymes.

In our measurements concerning prooxidative effects of mega doses of vitamin $\mathrm{C}$ it has been demonstrated that vitamin $\mathrm{C}$ supplied at 0.3, 0.6 and $0.9 \%$ affected lipid peroxidation (increased TBA-RS) (Niemiec, 2004). However, 8oxodG concentration was only elevated in livers of rats receiving $0.9 \%$. Also morphological evaluation of liver demonstrated necrotic changes in animals receiving $0.9 \%$ vitamin $\mathrm{C}$ (Ostaszewska et al., 2004), indicating that 8-oxodG concentration may be involved in necrosis but not in apoptosis.

Transition metals play an important role in forming genotoxic hydroxy radical (Aisen et al., 2001). It seems that the degradation of DNA is highly dependent on a distance between Fe and DNA and availability of Fe to form hydroxyl radical, because it has a mean half life of $10^{-9} \mathrm{sec}$. Toyokuni and Sagripanti (1996) investigated effects of $\mathrm{Fe}$ (III) or $\mathrm{Cu}$ (II) on degradation of DNA (level of DNA single-strand breaks and concentration of 8-OHdG in DNA). They demonstrated a high correlation between the concentration of $\mathrm{Fe}$ (III), as well as $\mathrm{Cu}$ (II) in the presence of ascorbinate, and the concentration of 8-OHdG. Therefore, it can be expected that the presence of $\mathrm{Fe}$ (III) close to ncDNA or mtDNA may generate hydroxyl radical and consequently oxidative degradation of DNA.

Furthermore, the cancerogenic transition metal ions $\mathrm{Ni}$ (II), $\mathrm{Cu}$ (II), Co ((II), Cd (II) are able to inhibit human 8-oxodGTPase (Kasprzak and Białkowski, 2000). Increasing concentration of 8-OHdG may be caused by an increase of $\mathrm{OH}$ generation by accumulating copper in hepatocytes or depressing the enzymatic activity for removing of 8-OHdG, which is dependent on divalent cations (Barciszewski et al., 1995). In our experiments (Niemiec, 2004) it has been demonstrated that the megadosis of vitamin $\mathrm{C}$ increased concentration of $\mathrm{Fe}$ but at the same time decreased concentrations of $\mathrm{Cu}$ and $\mathrm{Ca}$ in the liver of rats. Vitamin $\mathrm{C}$, as a reducing factor, probably elevated deposition of $\mathrm{Fe}$ (but not $\mathrm{Cu}$ ) in the liver. We also observed reduction of the total antioxidant status in serum and enhanced concentration of 8- 
$\mathrm{OHdG}$ in the liver. Ascorbate may affect availability of Fe for Fenton reaction and support formation of hydroxyl radical (Bartosz, 2003). The liver has a tendency of trapping Fe associated with ascorbate (Kang, 2001) and generating $\mathrm{OH}$ via Fenton reaction leading to oxidative alteration of DNA and liver lesions.

\section{ROS AS A REGULATOR OF CELL FUNCTIONING}

ROS is not only injurious by-product of cellular metabolism but also an essential participant in cell signaling and regulation (Kamata and Hirata, 1999). ROS, as well as nitrogen oxygen species (NOS) act as potential mediators able to affect signal transduction pathways of the proliferative and functional response of target cells. ROS may be generated as molecular messenger modifying growth factors, cytokines and other mediators (Keller and Matson, 1998).

It has been demonstrated (Sawosz et al., 2005) that restricted diet significantly decreased the level of insulin, leptin and thyroxin, however, it had no influence on redox state. Therefore, it can be suggested that the influence of dietary restriction on ageing may be caused by a signaling role of ROS but not due to cytotoxicity. Hence, energy restriction lowers the expression of genes responsible for oxygen respiration, in particular cytochrome c (to $1 / 23$ of normal), causing reduced metabolic rate (Lane, 2003).

Schmid et al. (1999) focused on a novel mechanism for "redox priming“ based on the predisposition of phosphocreatine together with $\mathrm{H}_{2} \mathrm{O}_{2}$ to serve as an alternate phosphate donor for the autophosphorylation of the insulin receptor kinase. The priming effect of $\mathrm{H}_{2} \mathrm{O}_{2}$ appears to involve conversion of four cysteine residues into sulphenic acid, which produces a structural change in insulin receptor kinase that allows for binding of phosphocreatine at a site distinct from the ATP (Thannickal and Fanburg, 2000). Furthermore, $\mathrm{H}_{2} \mathrm{O}_{2}$ acts as catalyst of reaction coupling diiodotyrosine into synthesis of thyroxine (Lamas et al., 1972).

It is well known the cytotoxic and gene regulating effects of tumor necrosis factor $\alpha$ (TNF $\alpha)$ are mediated by mitochondrial ROS formation (Goossens et al., 1995). ROS is involved in activation of a variety of kinases; protein kinase $\mathrm{C}$ (Nishikawa et al., 2000) as well as mitogen-activated protein kinase (MAPK) and tyrosine kinases (McCord, 2000).

Particularly important seems to be the role of mitochondria in regulation of redox cell signaling via ROS and reactive nitrogen species (NOS). Nitric oxide (NO) - most important NOS - is produced from arginine in a specific subcellular location but also in mitochondria (Giulivi et al., 1998). Brookes et al. (2002) suggested that the reaction between $\mathrm{NO}$ and $\mathrm{O}_{2}$ within the mitochondrial inner membrane is a significant pathway for $\mathrm{O}_{2}$ and $\mathrm{NO}$ consumption and the regulation 
of NO binding to cytochrome $\mathrm{c}$ oxidase. Consequently, NO has the potential to regulate $\mathrm{O}_{2}$ gradient within tissues. Under physiological conditions for NO formation, the overall result is extension of $\mathrm{O}_{2}$ gradients and avoidance of hypoxia in cells most distal from the $\mathrm{O}_{2}$ supply (Brooks et al., 2002). As a source for the formation and target of modifications mediated by reactive oxygen and nitrogen species mitochondria are recognized as a site critical in cellular response to redox stress (Bailey et al., 2005).

Essential and also intriguing is the role of S and mainly of a thiol group (present in cysteine) acting as a counterbalance to oversupply of oxygen. When thiol groups are oxidized the hydrogen atom is extracted forming sulphur bonds, known as disulphide bridges. The thiol groups can also form S-nitrosothiol. The formation of either a disulphide bridge or an S-nitrosothiol modifies the structure of the functional protein in a reversible way. Furthermore, the oxidative state of thiols affects protein activity, acting as a molecular on-off switch (Griffiths, 2002). These reactions govern activities of functional proteins which stimulate the transcription of genes.

A cell being "stressed" first uses antioxidant enzymes and molecules and then oxidizes thiol groups of protein. As a result of this process the proteins acting as transcription factors are activated. The transcription factors which activities are controlled by the oxidation of thiol groups include: AP-1, P-53, proinflamatory NF$\kappa \mathrm{B}$ involved in activation of offensive genes and Nrf-2, stimulating expression of defensive genes responsible for producing antioxidants like SOD, katalase and GPx, as well as for synthesis of several proteins like iron binding proteins, metallothionein and haem oxygenase (HO-1). These proteins improve cell resistance against overall stress factors (Rabilloud et al., 2001; Mitsumoto et al., 2002).

The question is whether an oversupply of antioxidants protects thiol groups against oxidation preventing synthesis of anti-stress protein. The addition of taurine decreased oxidative degradation of DNA (8-oxodG) in pigs during stress induced by vitamin C (Sawosz et al., 2004). Probably, taurine, being an important donor of SH-groups, increased the pool of thiol groups available for oxidation. In consequence the antioxidative state of the organism was enhanced. The activity of SOD, GPx or the level of albumine did not increase, indicating that the threshold for synthesis of antioxidative compounds was elevated.

Moreover, metal-ion clusters in metallenzymes play a very important role in cellular signaling modified by ROS. The iron-sulphur tetranuclear $4 \mathrm{Fe}-4 \mathrm{~S}$ core is the most common of this prosthetic groups which is modyified by $\mathrm{O}_{2}^{--}$. Iron regulatory proteins which contain $4 \mathrm{Fe}-4 \mathrm{~S}$ cluster are sensitive to oxidation, and they may be targets of site-directed, metal-catalysed oxidation by ROS (Fenton chemistry), which marks them for ubiquitination and degradation. Therefore, ROS may be capable of regulating cell function by altering the stability of certain metal-containing proteins (Iwai et al., 1998; Thannickal and Fanburg, 2000). 


\section{ANTIOXIDANT A FOE OR A FRIEND}

It is interesting where is the border line between "good" and "bad" function of antioxidants throughout their control of ROS generation. Which level of antioxidants can sustain body homeostasis and whether an oversupply of antioxidants has a depressive effect on oxidative stress resistance? We have investigated effects of a number of dietary antioxidants during different states of organism in pigs and rats. The addition of $\alpha$-tocopherol to the diet increased content of n-3PUFA in tissues and decreased concentration of TBA-RS in serum of pigs receiving linseed oil (Sawosz, 1999). However, in pigs supplemented with lard there was no effect on TBA-RS but a significant decrease of n-3PUFA. These results indicate that antioxidative role of vitamin E may only take place during imbalance of redox homeostatsis (f. expl. triggered by PUFA). In the other experiment vitamin $E$ effectively reduced losses of cystein during storage of pork (Sawosz et al., 2003). Cystein is one of the most important sources of thiol groups which are final oxidative substrates after all other reserves are depleted.

High doses of vitamin $\mathrm{C}$ for growing rats caused oxidative stress characterized by increased concentration of TBA-RS in serum and 8odG in DNA of liver and provoked the oxidative burst of neutrophiles rats (Niemiec, 2004; Niemiec et al., 2005). The mega doses of vitamin $C$ did also degradate collagen structures of lens capsule of rats' eyes (Ostaszewska et al., 2005, personal communication). Furthermore, morphological examinations of the liver revealed three fold increases in a number of liver cells without or with degenerated nuclei, as well as liver necrosis (Ostaszewska et al., 2004). In the other experiment (Niemiec, 2004) rats were exposed to UV or IR radiation which causes oxidative stress. In both cases a supplement of vitamin $\mathrm{C}$ fortified state of oxidative stress (increase of TBA-RS in serum and 8odG in DNA). Prooxidative effects of vitamin C were verified in experiments with pigs (Sawosz, 2004), demonstrating degradation of DNA without changes of TBA-RS level. It is interesting to notice that the activity SOD increased, which may confirm the theory that prooxidative agents through generations of ROS can stimulate synthesis of antistress proteins (SOD).

\section{CONCLUSIONS}

All living organisms have a very efficient and complementary network of antioxidant defence. This antioxidative network is closely related with all metabolic processes and its action is a function of variety of internal and external factors. The internal factors are age, life stage, genetic origin and consequently abilities to response to stress, while the external factors are environmental and 
nutritional conditions which may depress or magnify body responses. Depending on the combination of these factors the living organism may show different requirements and responses to antioxidants. On the other hand, the oxidative stress is the only donor of ROS which is a necessary element of life. Thus antioxidants per se are neither good nor bad, but their action can either be helpful or unhelpful depending on requirements for ROS.

\section{REFERENCES}

Aisen P., Enns C., Wessling-Resnik M., 2001. Chemistry and biology of eucaryotic iron metabolism. Int. J. Biochem. Cell Biol. 33, 940-959

Asami S., Hirano T., Yamaguchi R., Tomioka Y., Itoh H., Kasai H., 1996. Increase of a type oxidative DNA danage, 8-hydroxyguanine, and its repair activity in humans leucocytes by cigarette smoking. Cancer Res. 56, 2546-2549

Bailey S.M., Landar A., Darley-Usmar V., 2005. Mitochondrial proteomics in free radical research. Free Radical Biol. Med. 38, 175-188

Barciszewski J., Barciszewska M.Z., Rattan S.I.S., Clark B.F.C., 1995. The structure and properties of 8-hydroxy-2'-deoxyguanosine - a novel marker in aging biomarker in aging and carcinogenesis studies. Polish J. Chem. 69, 841-851

Bartosz G., 2003. The Other Face of Oxygen. Free Radicals in Nature (in Polish). PWN, Warszawa, pp. 448

Brookes P.S., Levonen A.-L., Shiva S., Sarti P., Darley-Usmar V.M., 2002. Mitochondria: regulators of signal transduction by reactive oxygen and nitrogen species. Free Radical Biol. Med. 33, $755-764$

Cadenas E., 1989. Biochemistry of oxygen toxicity. Annu Rev. Biochem. 58, 79-110

Dizdaroglu M., 1991. Chemical determination of free radical-induced damage to DNA. Free Radical Biol. Med. 10, 225-242

Fu C., Xi L., Wu Y., McCarter R., Richardson A., Hickey M., Han E.-S., 2004. Hepatic genes altered in expression by food restriction are not influenced by the low plasma glucose level in young male GLUT4 trangenic mice. J. Nutr. 134, 2965-2974

Giulivi C., Poderoso J.J., Boveris A., 1998. Production of nitric oxide by mitochondria. J. Biol. Chem. 273, 11038-11043

Goossens V., Grooten J., De Vos K., Fiers W., 1995. Direct evidence for tumor necrosis factorinduced mitochondrial reactive oxigen intermediates and their involvement in cytotoxicity. Proc. Nat. Acad. Sci. USA 92, 8115-8119

Griffiths H.R., 2002. The influence of diet on protein oxidation. Nutr. Res. Rev. 15, 3-17

Halliwell B., Gutteridge J.M.C., 1989. Free Radical in Biology and Medicine. New York, Oxford Press, pp. 22

Higuchi Y., 2003. Chromosomal DNA fragmentation in apoptosis and necrosis induced by oxidative stress. Biochem. Pharmacol. 66, 1527-1535

Iwai K., Drake S.K., Wehr N.B., Weissman A.M., La Vaute T., Minato N., Klausner R.D., Levine R.L., Rouault T.A., 1998. Iron-dependent oxidation, ubiquitination and degradation of iron regulatory protein-2: imlications for degradation of oxidised proteins. Proc. Nat. Acad. Sci. USA 95, 4924-4928

Kamata H., Hirata H., 1999. redox regulation of cellular signaling. Cell Signal. 11, 1-14 
Kang J.O., 2001. Chronic iron overload and toxicity: clinical chemistry perspective. Clin. Lab. Sci. 14, 209-219

Kasprzak K.S., Białkowski K., 2000. Inhibition of antimutagenic enzymes, 8-oxo-dGTPase, by carcinogenic metals. recent developments. J. Inorg. Biochem. 79, 231-236

Keller J.N., Mattson M.P., 1998. Role of lipid peroxidation in modulation of cellular signaling pathway, cell dysfunction and death in the nervous system. Rev. Neurosci. 9, 105-116

Lamas L., Dorris M.L., Taurog A., 1972. Evidence for a catalytic role for thyroid peroxidase in the conversion of diiodotyrosine to thyroxine. Endocrinology 90, 1417-1426

Lane N., 2003. Oxygen. The Molecules that Made the Word. Oxford University Press. UK, pp. 382

Li Y., Huang T.T., Carlson E.J., 1995. Dilated cardiomopathy and neonatal lethality in mutant mice lacking superoxide dismutase. Nat. Genet. 11, 376-381

Lobrich M., Ikepeme S., Kiefer J. 1994., DNA double strand break measurement in mammalian cells by pulsed-field gel electrophoresis: an approach using restriction enzymes and gene probing. Int. J. Radiat. Biol. 65, 623-630

Martin G.M., Loeb L.A., 2004. Mice and mitochondria. Nature 429, 357-359

McCord J.M., 2000. The evolution of free radicals and oxidative stress. Amer. J. Med. 108, 652-659

Mitsumoto A., Takeuchi A., Okawa K., Nakagawa Y.A., 2002. A supset of newly synthesised polypeptides in mitochondria from human endothelial cells exposed to hydroperoxide stress. Free Radical Biol. Med. 32, 22-37

Niemiec T., 2004. Effect of dietary vitamin $\mathrm{C}$ on antioxidative and nonspecific resistance in rats expose to UV and IR radiation. PhD Thesis. Warsaw Agricultural University, pp. 104

Niemiec T., Sawosz E., Chwalibog A., 2005. Effect of addition of L-ascorbic acid megadoses to the diet on the antioxidative/oxidative state in the rats. J. Anim. Feed Sci. 14, Suppl. 1, 551-554

Nishicava T., Edelstein D., Du X.L., Yamagishi S., Matsumura T., Kaneda Y., Yorek M.A., Beebe D., Oates P.J., Hammes H.P., Giardino I., Brownlee M., 2000. Normalizing mitochondrial superoxide production block three pathway of hyperglycaemic damage. Nature 404, 787-790

Ostaszewska T., Sawosz E., Niemiec T., Bielecki W., 2004. Effect of the addition of L-ascorbic acid megadoses to the diet on morphology of the liver in rats. J. Anim. Feed Sci. 13, Suppl. 2, 47-50

Rabilloud T., Heller M., Rigobello M.P., Aebersol R., Lunardi J., 2001. The mitochondrial antioxidant defence system and its response to oxidative stress. Proteomics 1, 1105-1110

Riley A., 1994. Free radicals in biology: oxidative stress and the effects of ionizing radiation. Int. J. Radiat. Biol. 1, 27-33

Sawosz E., 1999. Effect of diet enriched with polyunsaturated fatty acids and $\alpha$-tocopherol acetate and sodium ascorbinate on fatty acids content in muscles tissue of growing rats and pigs. Warsaw Agricultural University Press. Warsaw (Poland), pp. 127

Sawosz E., Orzechowska A., Niemiec T., Strawa A., Ostaszewska T., 2003. Vitamin C as modifying factor of true digestibility of amino acids in pork meat stored under different conditions. Zesz. nauk. Prz. hod. 70, 35-42

Sawosz E., Strawa A., Chwalibog A., Kosieradzka I., Niemiec T., 2004. Influence of energy and protein concentration in the diet on antioxidative/oxidative state in growing pigs. Proceedings of $8^{\text {th }}$ Meeting of the European Society of Veterinary and Comparative Nutrition. Budapest (Hungary), pp. 229-230

Sawosz E., Strawa A., Chwalibog A., Niemiec T., Kosieradzka I., Dutkowska I., 2004. Effect of vitamins $\mathrm{E}, \mathrm{C}$ and taurine on the oxidative state of DNA in the liver of growing pigs. J. Anim. Feed Sci. 13, Suppl. 2, 51-54

Sawosz E., Chwalibog A., Skomiał J., Kosieradzka I., Zięcik A.J., 2005. Effect of dietary energy concentration on hormonal profile and lipid metabolism in growing pigs. J. Anim. Feed Sci. 14, Suppl. 1, 395-398 
Schmid E., Hotz-Wagenblatt A., Hacj V., Droge W., 1999. Phosphorylation of the insulin receptor kinase by phosphocreatine in combination with hydrogen peroxide: structural basis of redox priming. FASEB J. 13, 1491-1500

Slater A., Stffan C., Nobel I., Orrfni S., 1995. Signaling mechanism and oxidative stress in apoptosis. Toxicol. Lett. 82, 149-153

Soultanakis R.P., Melamede R.J., Bespalov I.A., Wallace S.S., Beckman K.B., Ames B.N., Taaties D.J., Janssen-Henniger Y.M.W., 2000. Fluorescence detection of 8-oxo-guanine in nuclear and mitochondrial DNA of cultured cells using a recombinant Fab and confocal scaning laser microscopy. Free Radical Biol. Med. 28, 987-998

Thannickal V.J., Fanburg B.L., 2000. Reactive oxygen species in cell signaling. Amer. J. Physiol. Lung Cell M. Ph. 279, 1005-1028

Toyokuni S., Sagripanti J.-L., 1996. Association between 8-hydroxy-2`-deoxyguanosine formation and DNA strand breaks mediated by copper and iron. Free Radical Biol. Med. 20, 859-864

Trifunovic A., Wredenberg A., Falkenberg M., Spelbrink J.N., Rovio A.T., Bruder C.E., BohloolyY.M., Gidlof S., Oldfors A., Wibom R., Tornell J., Jacobs H.T., Larsson N.-G., 2004. Premature ageing in mice expressing defective mitochondrial DNA polymerase. Nature 429, 417-423

Yakes F.M., Van Houten B., 1997. Mitochondrial DNA damage is more extensive and persist longer than nuclear DNA damage in human cells following oxidative stress. Proc. Nat. Acad. Sci. USA 94, 514-519

\section{STRESZCZENIE}

\section{Wpływ żywienia na stres oksydacyjny}

Chociaż tlen jest cząsteczką niezbędną do procesów katabolicznych i anabolicznych zachodzących w organizmie zwierząt i człowieka, jest także źródłem reaktywnych form tlenu (ROS). Stres oksydacyjny pojawia się wówczas, gdy ilość powstałych ROS przekracza komórkową zdolność antyoksydacyjną, powodując oksydatywne zniszczenie struktury DNA, a w konsekwencji zakłócenie ścieżki przemian tłuszczów, białek i węglowodanów.

Mitochondrialny łańcuch oddechowy jest głównym miejscem występowania wolnych rodników o właściwościach genotoksycznych. ROS są nie tylko genotoksyczne w odniesieniu do mitochondrialnego DNA, ale także w stosunku do DNA zawartego w jądrze i dużo uwagi poświęca się jego uszkodzeniu w wyniku oksydacji. Przypuszcza się, że wydłużenie długości życia można osiągnąć przez ograniczenie ilości energii powodującej zmniejszenie intensywności przemian metabolicznych, a przez to redukcję procesów oksydacyjnych i powstawanie ROS.

W przeglądzie omówiono wyniki naszych ostatnich badań dotyczących procesów oksydacyjnych zachodzących przy ograniczonej podaży energii w paszy, dodatku ubichinonu, witamin C i E oraz tauryny i ich wpływu na wybrane wskaźniki komórkowe i morfologiczne w stresie oksydacyjnym u szczurów, świń i koni. Opierając się na współczesnej literaturze oraz badaniach własnych można stwierdzić, że powstawanie ROS jest niezbędnym elementem istnienia i odpowiedzi układu antyoksydacyjnego, związanego z podstawowymi procesami życiowymi, wywołane zapotrzebowaniem na ROS. 